\title{
Supermajority in Parliamentary Systems - A Concept of Substantive Legislative Supermajority: Lessons from Hungary
}

\author{
ZoltÁn PozSÁR-SzentMIKLÓSY*
}

\begin{abstract}
This paper focuses on the theoretical grounds of supermajority, its special relevance in parliamentary systems and the related experiences from Central and Eastern Europe, especially Hungary.

In parliamentary systems, the support of the parliamentary majority is a necessity and sufficient condition for governance - there is no need for supermajoritarian decision-making in issues of daily politics. A qualified majority has a different function and is an internal institutional limit of the legislative power - protecting the minority interests against the unilateral decisions of the majority in the most important issues of the political community.

The Hungarian situation from 2010-2015 demonstrates that minorities cannot influence the decisions where the supermajority represents a one-party opinion. Moreover, decisions of the supermajority can block future modifications of the future parliamentary majority as well. It will be argued in this paper that only a substantive approach to supermajority can support its basic function.
\end{abstract}

Keywords: parliamentary systems, legislative supermajority, protection of minorities, substantive approach

\section{IDENTIFYING THE CHALLENGE}

The concept of supermajority or qualified majority can be found in the practice of numerous parliaments. Constitutional amendments, legislative acts in some areas of law specified in constitutions, e.g. organic laws in France and Spain, and even the election of certain government officials, leaders of independent state organs or judges often require the support of higher proportion of MPs than ordinary decisions in parliaments. It is common in these decisions that they are related to issues which have high importance - both from the constitutional and political point of view.

It is appropriate to examine constitutional amendments separately from the above mentioned decisions of the legislature as, from the theoretical point of view, the constituent power and the constitution-amending power are always distinct from the legislative power. There are also various types of amendment rules, including ones which are very similar to ordinary parliamentary decisions.

A supermajority, however, is not a necessary requirement related to the most important decisions of legislation. Many constitutions do not prescribe special legislative topics which would need higher support than the majority. ${ }^{1}$ Similarly, in some cases only political culture and non-binding rule guides the legislature to build up wide support when electing or appointing office-holders. ${ }^{2}$ Countries which do not have a long-standing democratic tradition, like Hungary and other countries in Central and Eastern Europe, cannot base their

* assistant professor, ELTE Eötvös Loránd University (Budapest) Faculty of Law, Department of Constitutional Law. E-mail: pozsarz@ajk.elte.hu

1 One can mention the Basic Law for the Federal Republic Germany, the Constitution Acts of Canada, the Constitution of the Kingdom of the Netherlands, the Constitution of Finland.

2 The appointment procedure of the Nordic and common law supreme courts is often guided by constitutional tradition. See: The Composition of Constitutional Courts (1997) 1.3. 
practice only on political culture. In their case, supermajority requirements, which bind the parliament, are constitutional safeguards against the exclusive and excessive use of power of a certain political group.

In Hungary, the conservative political parties (Fidesz ${ }^{3}$ and $\mathrm{KDNP}^{4}$ ) formed the governing coalition with two-thirds majority of the parliamentary seats between 2010 and 2015. ${ }^{5}$ During this period, the National Assembly, by using the supermajority power, enacted the new constitution of the country, dozens of cardinal acts and elected a number of government officials, leaders of independent state organs and justices of the Constitutional Court. ${ }^{6}$ All these enactments were supported exclusively by the governing coalition. Even if the constitution-making process and constitutional amendments are not taken into consideration, the question arises whether this use of the legislative power is in accordance with the basic function of supermajority.

For the purposes of this analysis, the explanation offered by John O. McGinnis and Michael B. Rappaport will be used. In their view, supermajority in general can be considered as a constraint on the legislative power. ${ }^{7}$

The paper focuses on the theoretical grounds of supermajority, its special relevance in parliamentary systems and the related experiences from Central and Eastern Europe, especially Hungary. A possible approach to supermajority which supports its basic function based on these findings, will also be presented.

\section{THE FUNCTION OF SUPERMAJORITY}

Why are constraints on the majoritarian decision-making of the legislative power needed? What are the motives behind this idea?

Majoritarian decision-making is inevitable in democracies. In modern societies, which are divided by different experiences, preferences and opinions of their members, there is no better option to reach a decision which represents the presumed interest of the community. This is also true in the case of elected bodies when taking into account the functioning of representative democracy. If representative bodies (parliaments) are formed based on free and fair elections, then the majoritarian decisions of these, from the formal point of view, can be considered without doubt legitimate.

However, the support of the majority is not the only requirement related to decisionmaking in modern democratic societies. The famous phrase of Alexis de Tocqueville about the "tyranny of the majority' 8 demonstrates that the interests of the actual majority in some

3 Alliance of Young Democrats.

${ }^{4}$ Christian Democratic People's Party.

5 This period includes two parliamentary terms: 2010-2014 and the first year of the 2014-2018 term. Then the governing coalition lost its two-thirds majority due to two consecutive by-elections organised in single-member constituencies.

${ }^{6}$ Regarding the activity of the justices of the Constitutional Court elected in 2011 see: Analysis of the Performance of Hungary's 'One-Party Elected' Constitutional Court Judges between 2011 and 2014. (2014)

7 As a decision-making rule, supermajority differs both from ordinary (majoritarian) decisionmaking and absolute constitutional limitations (e.g. clauses on the protection of certain fundamental rights). See: McGinnis and Rappaport (1999) 399-402.

8 See Democracy in America (1946) Chapter 15 199-214. James Madison is often cited in this regard as well. [See The Federalist Papers (1961) Federalist no 10.]. However, the assumption that in 
cases can counter the rights or interests of minorities in a way which is not acceptable. This is the case when fundamental rights are limited, other constitutional values are infringed or certain minorities simply do not have the chance to raise their voice. Rules which function as safeguards and techniques related to the decision-making process can also effectively prevent such situations. In the case of parliaments, the veto power of the head of the state and the possible judicial review of the legislative decisions are traditional external limits of majoritarian power. The open debate in parliament which can deliberate alternative opinions (including the work in committees and even the possibility of filibuster) and supermajority requirements can be considered to be internal limits of the majority. All these lead to a decision-making process which is not only legitimate and democratic from the formal point of view but also represents substantive democratic values.

Supermajority rules, according to this classic approach, can protect the interests of minority groups. Minority groups can have not only the chance to raise their voice but also the possibility to take part in the decisions as some decisions require the support of more than a simple majority of MPs. Conversely, the classic critical approach argues that in these cases minorities can even block decisions and that is why their votes, from the substantive point of view, have more weight, in contradiction to the equality of mandates. ${ }^{9}$

These approaches can be systematized based on a deeper analysis as well. James M. Buchanan and Gordon Tullock, in their classic book (1962) combining economics and political theory, refer to the effects of qualified majority voting: 'the expected external costs would be reduced, but the decision-making costs would be increased'10 - the aggravation of the decision-making procedure leads to more stable results.

In recent years (2014), Melissa Schwartzberg published an impressive book in which she analyses the origins and effects of supermajority from the point of view of political theory and social choice theory. ${ }^{11}$ According to her approach, there are three justifications of the supermajority rule: the fostering of consensus; increasing institutional stability and providing protection to minorities. Her opinion is that there are normatively superior decision-making procedures that also achieve these aims, without suffering the normative drawbacks of supermajoritarianism - the most important being the undemocratic character as it provides a minority with a veto. ${ }^{12}$

Adrian Vermuele in his review on Schwartzberg's book ${ }^{13}$ expressed further important arguments related to the supermajority dilemma. He argues that

simple majority rule is the only approach that respects equal treatment of voters (anonymity) and equal treatment of the options before the group (neutrality). Supermajority rule, by contrast, in its ordinary form violates neutrality, because it

Federalist 10 Madison referred to the protection of the rights of minorities is contestable. Anthony McGann argues that Madison did not depart from the majority rule as "the only solution to majority tyranny given in Federalist 10 is to have a large "extended republic" where a single cohesive majority (which could dominate everyone else) would not exist'. See McGann (2006) 91, 111.

9 See Sajó (1999) 138.

10 Buchanan and Tullock (1999) 155.

11 Schwartzberg (2014) 216.

12 See Tipler (2016) 5.

13 Vermuele (2014). 
privileges one of the options - the status quo option of leaving everything as it is, an option that will become the group choice so long as a sufficient minority supports it. ${ }^{14}$

Vermuele doubts whether supermajority rules can protect minorities as the question depends on "who "the minority" is or will be'. ${ }^{15}$

It is worth noting that the argument that supermajority rules violate neutrality (as described above) can also be challenged. Michael B. Rappaport, referring to his analysis written with John O. McGinnis (mentioned above), argues that 'all that the violation of the neutrality condition shows is that there is a privileging of a decision (as compared to majority rule) and that this privileging needs a justification'. In his view, it is possible to justify such privilegization in exceptional cases. ${ }^{16}$

Regardless of which argument is given priority, all interpretations fit into the concept of supermajority as a constraint on the legislative power. ${ }^{17}$ And the protection of minority interests seems to be the most significant motive behind these constraints. Critical approaches do not challenge this function but are rather sceptical about its efficiency in this regard and accord more weight to majority decisions composed by identical and equal individual opinions.

\section{SUPERMAJORITY IN PARLIAMENTARY SYSTEMS}

The function of protecting minorities can be more visible when attention turns to parliamentary systems regarding the question of legislative supermajority. It is in the very nature of the parliamentary systems that a government can only act with the support of the parliamentary majority. ${ }^{18}$ The executive must answer to the legislative branch, which has the power to bring the mandate of the government to an end by submitting a motion of no confidence with a simple majority vote. The executive power (or the head of the state) usually has the power to dissolve the parliament when there is no majority which can support government. Within these circumstances, (simple) majority voting is the essence of governing whereas qualified majority is always an exception.

In this respect, there is a serious challenge of basic parliamentary model. Bruce Ackerman describes that '(I)t is wrong (...) to suppose that every electoral victory marks a broad and deep mandate from the People for the leading proposals set out by the victorious party or coalition.' Furthermore, '(T)he Westminster system cements this mistake into constitutional law by awarding plenary lawmaking authority to the victors regardless of the quality of their electoral majority. ${ }^{19}$ Ackerman argued that it is essential to have constraints against the presumed limitless power of the parliamentary majority, like the referenda and the possibility of judicial review. ${ }^{20}$

14 See Vermuele (2014) (This argument is called May's Theorem in literature.).

15 See Vermuele (2014).

16 Rappaport (2014).

17 See the reference to John O. McGinnis's and Michael B. Rappaport's work in the introduction part.

18 This feature can be defined as the 'essence of parliamentarism'. See Bradley and Pinelli (2012) 651.

19 See Ackerman (2000) 665.

20 See Ackerman (2000) 668. 
At this point it is worth looking back to the English roots of parliamentarism. Even Albert Venn Dicey, a great supporter of parliamentary sovereignty recognizes that the parliamentary power has external and internal limits. The possibility that the people will disobey or resist the laws ${ }^{21}$ can be considered to be an external limit, while the attitude of the decision-makers toward public affairs, bound by the historical circumstances and the morality of the society, ${ }^{22}$ is an internal limit. However, his assessment nowadays seems to be too optimistic when stating that 'the permanent wishes of the representative portion of Parliament can hardly, in the long run differ from the wishes of the English people or at any rate of the electors; that which the majority of the House of Commons command, the majority of the English people usually desire. ${ }^{23}$

Ackerman is right when arguing for institutional constraints of the parliamentary majority - his approach focuses on solutions which are related to the principle of separation of powers. [In part II. of this paper I have called similar techniques (the veto power of the head of the state and the possible judicial review of the legislative decisions) external limits of the power of the parliamentary majority.] Taking also into consideration Dicey's approach, these should be labeled external institutional limits. However, internal institutional limits (rules related to the decision-making process of parliament including supermajority voting rules) also should be taken into consideration.

Both external and internal institutional limits have special relevance in parliamentary systems as they can frustrate the parliamentary majority and also have an impact on the position of the government. When the effects of these limits are too strong, the government is forced to make political changes in order to maintain the confidence of the parliamentary majority. The parliamentary majority by definition supports the government as long as it has their confidence whilst parliamentary minority groups act as watchdogs. ${ }^{24}$ Party discipline is also very strict in parliamentary system ${ }^{25}$ and in most of the cases, every single opposition MP will act according to this role. Internal institutional limits can support, in this regard, parliamentary minority groups only if these function effectively. In parliamentary systems, ordinary majoritarian decisions have more weight in expressing the will of the majority. That is why the constraints of the majoritarian decision-making have more relevance in the protection of minority interests. These particularities of the parliamentary model do not exclude compromises between majority and minority groups in important cases. A classic argument demonstrates that the dynamics of the parliamentary democracy is based on the possibility of interchange of positions of these groups which sustains the compromise between them. ${ }^{26}$

${ }^{21}$ See Dicey (1886) 70.

22 See Dicey (1886) 73-74.

${ }^{23}$ See Dicey (1886) 77.

${ }^{24}$ Regarding the role of minority groups see the assessment of Professor Currie on the German experiences. Currie (2008) 2147.

25 See Bradley and Pinelli (2012) 658.

${ }^{26}$ Professor Basset assumes that '(M)ajority and minority alike are themselves based largely upon compromise, and the compromise between them secured and necessitated by their interchange of positions is only the last stage of a long series and forms a starting point for new series. The process in continuous.' Basset (1965) 125-26. 


\section{THE CONSTITUTIONAL POLITICS RELATED TO THE SUPERMAJORITY IN HUNGARY 2010-2015}

In 1989-1990, after the fall of the Iron Curtain, Central and Eastern European countries built their constitutional system on popular sovereignty; separation of powers; the rule of law and the protection of human rights. The transition from authoritarian regimes dominated by a single party to stable democracy is not a quick process as it takes time until basic constitutional principles dominate the daily practice of the state organs and political culture deepens.

In Hungary, the 1989 Constitution prescribed a two-thirds majority of the MPs present at the sitting of the National Assembly for enacting laws that could be considered as 'areas that present the greatest risk of abuse by a ruling coalition in a state characterized by remnants of Communism' ${ }^{27}$ The idea behind this concept was that the two-thirds majority rule will force governing and opposition parties to reach a compromise in these issues. The selection of these topics was not solely based on special constitutional relevance but also on their political weight, given that none of the political parties had confidence in its fellows. Accordingly, these laws were not of a higher rank than ordinary laws in the legal system. ${ }^{28}$ Ordinary laws, according to the very nature of parliamentary systems, required a simple majority. 'Two-thirds majority acts' were considered to have higher political importance, as they typically regulated the exercise of certain fundamental rights and the legal status of the most important state organs. The Constitutional Court also expressed that the 'two-third majority acts' had the function to build up wide political support, different from the majority. ${ }^{29}$ However, it was controversial that, at the same time, other fundamental rights and state organs (considered to have less political weight) were regulated in ordinary laws. ${ }^{30}$

The new Fundamental Law of Hungary, which entered into force on the $1^{\text {st }}$ of January 2012, has kept this technique by prescribing the support of two-thirds majority of the MPs present at the sitting of the National Assembly (relative supermajority) in the case of cardinal acts. At present, 27 topics shall be regulated in cardinal acts. ${ }^{31}$ The same relative supermajority rule is applied for enacting the Standing Orders of the Parliament and in the case of 29 other decisions, distinct from the legislative topics mentioned above. Furthermore, in 16 other cases (mostly election of heads of independent state organs) two-thirds of all MPs (absolute supermajority) is required for a decision to be adopted. In one special case, support of four-fifth of the MPs present is required..$^{32}$ One can conclude that supermajority

27 Ethan Klingsberg refers to media, military, police, local self-government, religion, ethnic minorities, citizenship, national security. See Klingsberg (1993) 47.

28 There are also scholar works which contest this approach, arguing that 'two-thirds majority laws' were of higher rank than ordinary laws. See Jakab (2007).

${ }^{29}$ See Decision 4/1993. (II. 12.) CC, part II. It is worth mentioning that the critique of the institution of the 'two-third acts' (both from the legal and political point of view) also appeared al in a dissenting opinion. See: Dissenting opinion of Justice Péter Schmidt, Decision 4/1993. (II. 12.) CC.

${ }^{30}$ For a general analysis of the decision-making competences of the National Assembly in the examined period see: Smuk (2008).

31 Jakab and Szilágyi (2016) 4-7. One can add that due to the coincidence of the topics regulated, the list of cardinal acts on the website of the Hungarian National Assembly contains 32 items. See: Sarkalatos törvények jegyzéke (2015).

32 Deviating from the provisions of the Standing Orders. 
rules are present in a significant proportion in the present decision-making practice of the Hungarian National Assembly. ${ }^{33}$

At this point, it is worth having a look at the experiences of two other countries from the region which are in a similar position: the Czech Republic and Slovenia. Both countries have a parliamentary system of government (like Hungary), operate with some legislative acts which need supermajority (like the Hungarian cardinal acts) and experienced the transition period with similar conditions. The Czech Republic (as a member of Czechoslovakia), for a short period between 1990-1992, experienced that one party (the Civic Forum) won $62 \%$ of the parliamentary seats. The major parties won parliamentary seats in very similar proportions in all other parliamentary elections, in none of the cases forming governing coalitions with a supermajority in the Chamber of Deputies. ${ }^{34}$ In Slovenia, since 1990, all governments have been coalition governments. ${ }^{35}$ No situation arose in which the governing parties could pass decisions in Parliament which require supermajority without the support of the opposition parties.

Contrary to the abovementioned experiences from the region, in Hungary the parties forming the present governing coalition maintained supermajority of the parliamentary seats on their own between 2010 and $2015 .{ }^{36}$ There was no need for the support of the opposition parties in the most important constitutional and political issues - these questions were decided exclusively by the governing coalition. As mentioned previously, during this period the National Assembly - by using the supermajority power - enacted the new constitution of the country, dozens of cardinal acts and it elected a number of government officials, leaders of independent state organs including the president of the Curia (the Supreme Court of Hungary), justices and president of the Constitutional Court.

The Fundamental Law entered into force in 2012 and since then, the nature of cardinal acts and the constitutional politics related to them has changed in Hungary. Taking into consideration the subjects of the regulation, there is a shift from mostly consent-orientated issues to typical topics of governance, e.g., family legislation, social or taxation policy. Furthermore, the Government, with the exclusive support of its supermajority in the National Assembly, proposed the creation of new cardinal acts and the amendment of existing ones as a matter of daily politics. In this regard, the cardinal acts - similarly to the two-thirds acts of the transition period - still represent topics which 'present the greatest risk of abuse of power by a ruling coalition' ${ }^{37}$ and have at their roots the absence of

33 For a detailed list of decisions requiring qualified majority see: Voting: Decisions requiring a qualified majority (2017).

34 After the 2006 parliamentary elections even a deadlock occurred, given the fact that none of the rival political parties (together with their possible allies) could have the support of more than 100 MPs in the 200 seat Chamber of Deputies. See: Civic Democrats win largest share of popular vote; election ends in deadlock (2006).

35 See Governments of the Republic of Slovenia (2014).

36 In the period between 1994-1998 the governing socialist and liberal coalition had also twothirds majority in the National Assembly and in exceptional cases also used its supermajority power exclusively. However, the governing parties refused to bear the whole political responsibility for the enactment of a new constitution, therefore the constitution-drafting process was designed to involve opposition parties as well. The process was time-consuming and at the end of the parliamentary term the participants lost their interest in cooperation. For a detailed analysis see Arato and Miklósi (2010) $370-72$.

37 See Klingsberg (1993) 47. 
confidence in other political actors. However, the political circumstances are clearly different from those of the transition period. Before the transition, the political actors specified those legislative topics which required two-thirds majority as a result of a compromise, while the legislative topics which shall be regulated in cardinal acts were specified in the Fundamental Law unilaterally by the governing political side. The Venice Commission of the Council of Europe underlined that (a) in many cases there is no justification for the requirement of two-thirds majority, (b) due to their nature, many issues regulated by cardinal acts should have been left to ordinary legislation and majoritarian politics and (c) there is a risk that the actual two-thirds majority can cement its political preferences. $^{38}$

The practice described above contradicts the philosophy of parliamentarism. ${ }^{39}$ According to the very nature of the parliamentary systems, a government can only act with the support of the parliamentary majority. In this regard, the support of the parliamentary majority is a necessary and sufficient condition for governance - there is no need for supermajoritarian decision-making in issues of daily politics. Qualified majority has a different function - as an internal institutional limit of the legislative power - protecting the minority interests against the unilateral and arbitrary decisions of the majority in the most important issues of the political community, e.g., fundamental rights, the basic structure of the constitutional organs, basic constitutional values.

The Hungarian experience in the recent years does not fit this interpretation, rather it demonstrates that in cases where the supermajority represents one party, opinion minorities cannot influence the decisions. ${ }^{40}$ Moreover, decisions of the supermajority can block future modifications by a future parliamentary majority as well. It is especially unique that in the present Hungarian case the governing coalition blocked itself because the actual majority is not a supermajority anymore. ${ }^{41}$

The governing coalition's loss of its supermajority power has led to a situation where it can no longer pass exclusively absolute supermajority decisions. The election of the new justices of the Constitutional Court on 22 November 2016 was the first case the governing coalition had to reach an agreement with one of the opposition parties in an absolute supermajority case. ${ }^{42}$ Given the fact that cardinal acts (many of these regulating issues of daily politics) require a relative supermajority, the modification of these can pass in the future with the exclusive support of the governing coalition if there are more opposition MPs absent from voting than members of the governing side - a condition which is highly unlikely.

There is a slight chance to get occasional support from the opposition for the proposals of the government requiring supermajority in parliament. ${ }^{43}$ Belonging to the governing or

38 See Opinion on the New Fundamental Law of Hungary (2011) 22-27.

39 According to Hans Kelsen, '(P)arlamentarism means government by a collegial organ democratically elected by the People based on universal, equal suffrage and the principle of majority.' Kelsen (2013) 48.

40 Many scholars argue that even the formal use of supermajority power to make transformative changes to the Constitution was undemocratic from a substantive point of view. See Kis (2012) 1-21.

${ }^{41}$ In the parliamentary term 2014-2018, since the by-elections of 2015.

42 See Parliament elects 4 top court judges, new chief (2016).

43 The sixth amendment to the Fundamental Law on 'terror threat situation' (14 June 2016) passed, while the proposed seventh amendment on the 'prohibition of settlement of foreign population in the territory of Hungary' failed (8 November 2016). 
the opposition side is a core element of identity of parliamentary parties and, like in other parliamentary systems, party discipline is very strict in the Hungarian National Assembly. As a consequence, not only the protection of minorities but the majoritarian decisionmaking itself, 'the essence of parliamentarism' 44 can face difficulties.

\section{A POSSIBLE SOLUTION: TAKING THE FUNCTION OF SUPERMAJORITY SERIOUSLY}

The experiences described above underline that the level of support required in a vote is not the only difference between majoritarian and supermajoritarian parliamentary decisions. A supermajority - as a constraint of the majoritarian legislative power - also has the substantive function of reaching a compromise between the governing side and the opposition in the most important cases. ${ }^{45}$ This function is central in issues which protect genuine minority interests and the basics of the constitutional structure, e.g. fundamental rights, the status of independent state organs and constitutional values. However, as the Hungarian example demonstrates, if this function is not explicitly guaranteed by law, a supermajority used in a formal way can ultimately undermine the values it is supposed to protect.

\section{LITERATURE}

Ackerman, Bruce, 'The New Separation of Powers' (2000) 113 Harvard Law Review 633-725.

Arato, Andrew and Miklósi, Zoltán, Constitution Making and Transitional Politics in Hungary in Miller, L. and Aucoin, L. (eds): Framing the state in times of transition: case studies in constitution making (United States Institute of Peace 2010).

Basset, Reginald G., The Essentials of Parliamentary Democracy (2nd ed. Barnes \& Noble 1965).

Bradley, Anthony W. and Pinelli, Cesare, 'Parliamentarism' in Rosefeld, Michel and Sajó, András (eds), The Oxford Handbook of Comparative Constitutional Law (Oxford University Press 2012) 650-70.

Buchanan, James M. and Tullock, Gordon, The Calculus Consent. Logical Foundations of Constitutional Democracy (vol 3, Liberty Fund 1999).

Currie, David P., 'Republication - Separation of Powers in the Federal Republic of Germany' (2008) 912 German Law Journal 2113-78.

Dicey, Albert Venn, Introduction to the Study of the Law of the Constitution (2nd ed. Macmillan and Co. 1886).

Hamilton, Alexander, Madison, James, and Jay, John, The Federalist Papers (New America Library 1961).

Jakab, András, A magyar jogrendszer szerkezete (Dialóg - Campus 2007).

Jakab, András and Szilágyi, Emese, 'Sarkalatos törvények a magyar jogrendben' in Jakab, András and Gajduschek, György (eds), A magyar jogrendszer állapota (MTA-TK-JTI 2016) 243-321.

Kelsen, Hans, The Essence and Value of Democracy (Urbinati, Nadia and Invernizzi Acetti, Carlo eds, transl Graf, Brian, Rowman \& Littlefield Publishers 2013).

Kis, János, 'Introduction. From the 1989 Constitution to the 2011 Fundamental Law' in Tóth, Gábor Attila (ed), Constitution for a Disunited Nation (Central European University Press 2012) 1-22.

Klingsberg, Ethan, 'Safeguarding the Transition' (1993) 2 East European Constitutional Review 44-48.

44 See Bradley and Pinelli (2012) 651.

45 The Venice Commission states that 'the requirement of a supermajority also underlines the need for a broad consensus'. See Opinion on the New Fundamental Law of Hungary (2011) 23. 
McGann, Anthony, The Logic of Democracy. Reconciling Equality, Deliberation and Minority Protection (University of Michigan Press 2006).

McGinnis, John O. and Rappaport, Michael B., 'Supermajority Rules as a Constitutional Solution' (1999) 40 (2) William \& Mary Law Review 365-470.

Rappaport, Michael B, 'More on Supermajority Rules: May's Theorem' (2014) Library of Law and Liberty, January 22, $2014<$ http://www.libertylawsite.org/2014/01/22/more-on-supermajorityrules-mays-theorem/> accessed 21 October 2017.

Sajó, András, Limiting Government: An Introduction to Constitutionalism (Central European University Press 1999).

Schwartzberg, Melissa, Counting the Many: The Origins and Limits of Supermajority Rule (Cambridge University Press 2014).

Smuk, Péter, Ellenzéki jogok a parlamenti jogban (Gondolat 2008).

Tipler, Kathleen, 'Review. Counting the Many: The Origins and Limits of Supermajority Rule' (2016) 15 (1) Contemporary Political Theory 5-7.

Tocqueville, Alexis de, Democracy in America (transl Henry Reeve) (Oxford University Press 1946).

Vermuele, Adrian, 'The Filibuster Does Not Protect Minority Interests. And other reasons to reject supermajority requirements.' (2014) The New Republic, January 15, $2014<$ https://newrepublic. com/article/116172/against-filibusters-super-majorities-melissa-schwartzberg-reviewed $>$ accessed 21 October 2017.

\section{LINKS}

1. The Composition of Constitutional Courts (European Commission for Democracy through Law) (1997) <http://www.venice.coe.int/webforms/documents/default.aspx?pdffile=CDL-STD(1997) 020-e $>$ accessed 6 October 2017.

2. Analysis of the Performance of Hungary's "One-Party Elected" Constitutional Court Judges between 2011 and 2014. (Eötvös Károly Policy Institute, Hungarian Helsinki Committee, Hungarian Civil Liberties Union) (2014) <http://helsinki.hu/wp-content/uploads/EKINT-HCLUHHC_Analysing_CC_judges_performances_2015.pdf $>$ accessed 6 October 2017

3. Sarkalatos törvények jegyzéke (2015) <http://www.parlament.hu/documents/10181/62157/ sarkalatostvekjegyzeke.pdf/afc8f54c-81c8-470e-a16f-3a5691b4c1b3> accessed 6 October 2017

4. Voting: Decisions requiring a qualified majority (2017) $<$ http://www.parlament.hu/en/web/houseof-the-national-assembly/laws-requiring-a-two-thirds-qualified-majority $>$ accessed 6 October 2017

5. Civic Democrats win largest share of popular vote; election ends in deadlock (2006) $<$ http://www. radio.cz/en/section/bulletin/news--820\#1> accessed 6 October 2017

6. Governments of the Republic of Slovenia (2014) <http://www.vlada.si/en/about the government/ governments_of_the_republic_of_slovenia/> accessed 6 October 2017

7. Opinion on the New Fundamental Law of Hungary (European Commission for Democracy through Law) $(2011)<\mathrm{http}$ //www.venice.coe.int/webforms/documents/default.aspx?pdffile=CDLAD(2011)016-e > accessed 6 October 2017

8. Parliament elects 4 top court judges, new chief (November 22, 2016) $<$ https://dailynewshungary. com/parliament-elects-4-top-court-judges-new-chief/> accessed 6 October 2017 